\title{
The potential of agarwood as a climate- resilient livelihood option in Indonesia
}

Yusuf B Samsudin

Thifali Adzani

Muhamad Aditio Ramadian

Daisuke Naito

Himlal Baral 

Working Paper 271

\title{
The potential of agarwood as a climate- resilient livelihood option in Indonesia
}

\author{
Yusuf B Samsudin \\ Center for International Forestry Research (CIFOR) \\ Thifali Adzani \\ Development Planning Agency (BAPPEDA) of West Java Province \\ Muhamad Aditio Ramadian \\ Independent Scholar \\ Daisuke Naito \\ Center for International Forestry Research (CIFOR) \\ Graduate School of Agriculture, Kyoto University \\ Himlal Baral \\ Center for International Forestry Research (CIFOR)
}


Working Paper 271

C 2021 Center for International Forestry Research

(c) (i) Content in this publication is licensed under a Creative Commons Attribution 4.0 International (CC BY 4.0), http://creativecommons.org/licenses/by/4.0/

DOI: $10.17528 /$ cifor/008260

Samsudin YB, Adzani T, Ramadian MA, Naito D and Baral H. 2021. The potential of agarwood as a climate-resilient livelihood option in Indonesia. Working Paper 271. Bogor, Indonesia: CIFOR.

CIFOR

Jl. CIFOR, Situ Gede

Bogor Barat 16115

Indonesia

$T+62(251) 8622-622$

$\mathrm{F}+62(251) 8622-100$

E cifor@cgiar.org

\section{cifor.org}

We would like to thank all funding partners who supported this research through their contributions to the CGIAR Fund. For a full list of the 'CGIAR Fund' funding partners please see: http://www.cgiar.org/our-funders/

Any views expressed in this publication are those of the authors. They do not necessarily represent the views of CIFOR, the editors, the authors' institutions, the financial sponsors or the reviewers. 


\section{Contents}

Acknowledgments $\quad$ iv

1 Introduction $\quad 1$

2 Methods $\quad 3$

$\begin{array}{ll}2.1 \text { Study areas } & 3\end{array}$

$\begin{array}{ll}2.2 & \text { Methods and data analysis }\end{array}$

3 Agarwood planting, degradation of natural agarwood and regulation in Indonesia 5

4 Case studies from agarwood planting areas $\quad 7$

$\begin{array}{lll}4.1 & \text { Plantation systems } & 7\end{array}$

4.2 Products and marketing $\quad 8$

5 Developing paludiculture in degraded peatlands $\quad 11$

6 Key challenges and a way forward $\quad 13$

$\begin{array}{lr}\text { References } & 15\end{array}$

\section{List of figures and tables}

\section{Figures}

1 Agarwood plantation study locations in Central Bangka district, Bangka Belitung province and Balangan district, South Kalimantan province, Indonesia (layout: Agus M. Maulana/CIFOR) 3

2 Induction process using the microbial-biological method. Photos were taken during the induction training in West Nusa Tenggara Province, organized by FORDA, Ministry of Forestry, Indonesia. (Turjaman, Santoso and Subiakto 2011)

\section{Tables}

1 Census of agarwood plantation distribution in Indonesia

2 Agarwood market prices in South Kalimantan 


\section{Acknowledgments}

This study is part of the CGIAR Research Program on Forests, Trees and Agroforestry (CRP-FTA) and supported by the Ministry of Agriculture, Forestry and Fisheries (MAFF) of Japan under the Enhancing Climate-Resilient Livelihoods in Boreal and Tropical High Carbon Forests and Peatlands project. We would like to thank the Government of Japan and CGIAR Fund donors for their financial support.

We would like to thank Professor Mamoru Kanzaki from the Graduate School of Agriculture, Kyoto University and Double Degree Program of ITB \& Kyoto University for supporting the study in Bangka, and Professor (Ris) Maman Turjaman for his valuable critical input on the early draft of this paper. We would also like to thank the Central Bangka District Development Planning and Regional Development Research Agency for its facilitation during data collection in Bangka. Special thanks go to Agus M. Maulana for his layout of the study area maps. We express our gratitude to people in the study locations for sharing their time, knowledge and concerns. 


\section{Introduction}

Agarwood is a high-value tree commodity found in tropical forests in at least 12 countries in South and Southeast Asia, including Indonesia, Bangladesh, Cambodia, Viet Nam, Bhutan, Thailand, Lao PDR, Malaysia and Myanmar (Lee and Mohamed 2016). Agarwood resin has the blackish colour of heartwood (Turjaman, Hidayat, and Santoso 2016). It forms from a natural chemical barrier in the tree that protects against bacteria, fungi, insects and attacks from external agents (Compton and Ishihara n.d.; Nobuchi and Siripatanadilok 1991; Gerber and Hill 2005; Faizal et al. 2017). The most notable tree species that produce agarwood resin are from Aquilaria and Gyrinops genera (Compton and Ishihara n.d.).

Harvesters and consumers often rely on agarwood products from natural forests, which has caused overexploitation and threatens their survival (Karlinasari and Nandika 2016; Turjaman et al. 2016). Due to this overexploitation, Aquilaria spp. and Gyrinops spp. have been listed in Appendix II of the Convention on International Trade in Endangered Species of Wild Fauna and Flora (CITES), which restricts trading of listed species (Schmidt 2011).

In the global marketplace, distillate of old agarwood oil can reach up to USD 80,000/litre and agarwood chips can reach USD 100,000/kg for use in religious and cultural activities (Persoon 2007; Naziz, Das and Sen 2019; Ash and Nguyen 2020). Recognizing the economic opportunities the commodity provides, several local governments in Indonesia are promoting its cultivation through agarwood plantations. Most of these plantations are in Sumatra (53\%) and Kalimantan (38\%) (Table 1). Through the Ministry of Environment and Forestry (MoEF)'s Forest and Environmental Research, Development and Innovation Agency (FORDA) of the Republic of Indonesia, the government promotes research into methods to induce trees to form agarwood resin. MoEF also issued a regulation on agarwood cultivation, harvesting and trading in 2015. A FORDA study shows more than 3 million agarwood trees from various genera growing in 1,257 village regions in 21 provinces in Indonesia (Santoso et al. 2014; Santoso 2015 in Turjaman and Hidayat 2016) (see Table 1).

Agarwood cultivation shows promise for sustainable management and supply of agarwood resin to markets (Turjaman et al. 2016). However, effective inoculants are a key factor for determining successful cultivation (Turjaman et al. 2016). Having effective fungal inoculants would spur farmers' interest in practicing agarwood cultivation, whereas failure to develop inoculants will cause local community interest in developing agarwood to wane, and result in wild agarwood harvesting remaining high or even increasing.

Table 1. Census of agarwood plantation distribution in Indonesia

\begin{tabular}{llrrrrrr}
\hline No. & Region & Farmers & Villages & Subdistricts & Districts & Provinces & Tree numbers \\
\hline 1 & Sumatra & 939 & 160 & 55 & 30 & 8 & $1,800,471$ \\
\hline 2 & Kalimantan & 167 & 107 & 67 & 22 & 4 & $1,268,796$ \\
\hline 3 & Java & 3,473 & 905 & 420 & 47 & 4 & 107,848 \\
\hline 4 & Eastern Indonesia & 178 & 85 & 37 & 22 & 5 & 169,660 \\
\hline Total & & $\mathbf{4 , 7 5 7}$ & $\mathbf{1 , 2 5 7}$ & $\mathbf{5 7 9}$ & $\mathbf{1 2 1}$ & $\mathbf{2 1}$ & $\mathbf{3 , 3 4 6 , 7 7 5}$ \\
\hline
\end{tabular}

Sources: Santoso et al. 2014; Santoso 2015 in Turjaman and Hidayat 2016. 
Vast areas of peatland have been degraded by land-cover and land-use change, leading to forest fires (Carlson et al. 2012; Elz et al. 2015). These landscapes need to be restored to recover ecosystem services for human benefits. The five provinces of Kalimantan had around 2.8 million ha of degraded peatlands in 2018 (MoEF 2019). Peatland fires cause massive greenhouse gas emissions and contribute to climate change (Huijnen et al. 2016). While peatland restoration will bring climate benefits in a general sense, it could also provide multiple benefits to local communities by enabling sustainable livelihood options.

This paper seeks to understand the status of agarwood plantations in Indonesia. This includes the roles and policies of different government institutions, farmer harvesting methods, the status of local markets, trading, and other challenges. It analyses agarwood plantation development as an opportunity for reducing pressures on agarwood species in the wild. It also discusses the possibility of agarwood plantations as a livelihood option local communities can use to help restore degraded peatlands. 


\section{Methods}

\subsection{Study areas}

Central Bangka district in Bangka Belitung province and Balangan district in South Kalimantan province were chosen as study locations as they are known for their smallholder agarwood plantations (Turjaman and Hidayat 2017) and have established local markets.
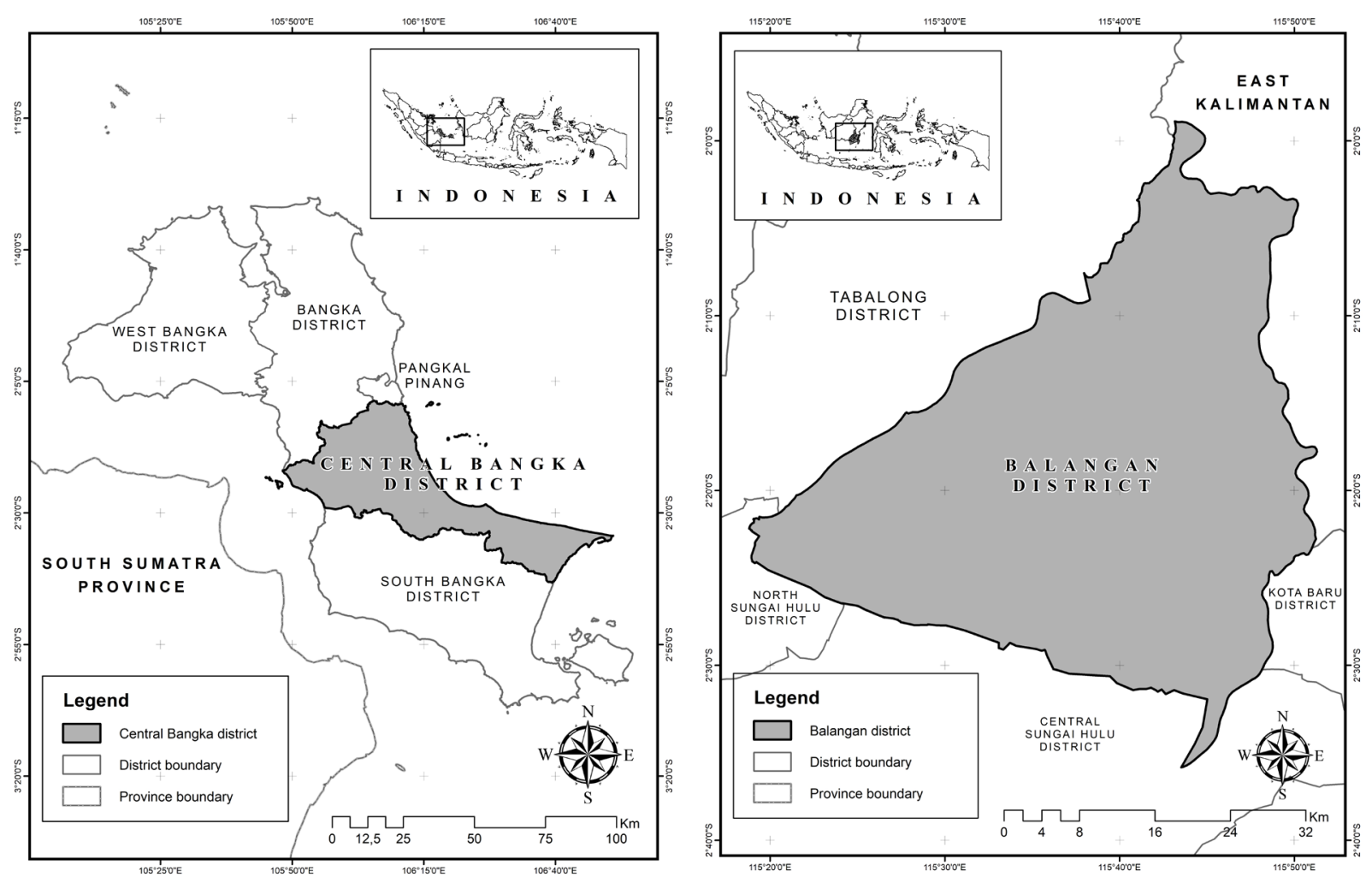

Figure 1. Agarwood plantation study locations in Central Bangka district, Bangka Belitung province and Balangan district, South Kalimantan province, Indonesia (layout: Agus M. Maulana/CIFOR)

\subsubsection{Central Bangka district, Bangka Belitung province}

Known by the local Malay community as garu or gaharu, agarwood was traditionally collected from the wild in Bangka Belitung province (interview with a farmer, March 2019). We chose Central Bangka ${ }^{1}$ for a case study because of its use of a cluster system for its agarwood plantations. This system is an integrated business model that conserves, plants, produces and maintains agarwood trees. Stakeholders in the system also conduct research relating to technological innovations for inoculation, which is jointly managed at the provincial and district level. The Indonesian government, as reflected in the Governor Decree No. 188.44/37/Dishut/2009 and the Director-General of Land Rehabilitation and Social Forestry of MoEF Decree No. SK.22/V-BPS/2010, promoted agarwood

1 Central Bangka district comprises seven subdistricts and 56 villages, has a total area of 2,126.36 km² and a population of 191,183 (Turjaman 2016). 
as a local flagship species (Tanaman Unggulan Lokal-TUL) to attract local community interests to restore degraded land and enhance their livelihoods (Burhan, 2009; Plantation and Forests Agency of Central Bangka District, 2013). Subsequently, more than 300,000 trees were planted in the district (Plantation and Forests Agency of Central Bangka District, 2013; interview with Central Bangka District Development Planning and Regional Development Research Agency-Bappelitbangda official, March 2019).

\subsubsection{Balangan district, South Kalimantan}

Known by the local Banjar people ${ }^{2}$ as garu or gaharu, agarwood has been extracted from the wild traditionally for hundreds of years in the region (interview with a female farmer, May 2019). Responding to the scarcity of wild agarwood in forests, a farmer became a local hero by producing agarwood seedlings from her 30 parent trees. The Balangan District Government followed up by enriching rubber tree plantations with agarwood trees using the Community Forest (Hutan Rakyat) scheme on over 250 ha of private land between 2005-2012 (lbid). Most agarwood plantations are in Batu Mandi, Halong and Juai subdistricts (Ibid). More than 12,500 Aquilaria spp. trees were planted from seedlings supplied from the 30 parent trees (Ibid). Market destinations for agarwood produced in this region are Middle Eastern countries, including Saudi Arabia, Yemen, the United Arab Emirates and Oman (Ibid).

Balangan, established through Law No. 2/2003, is one of the youngest districts in South Kalimantan province. Its total area of around 1,819.75 $\mathrm{km}^{2}$ comprises 179,269 ha of land and 8,563 ha of wetlands, including peat swamps and rivers. As of December 2011, approximately 125,000 agarwood trees had been planted in Balangan (Antaranews.com 2011). The Peatland Restoration Agency or Badan Restorasi Gambut (BRG) ${ }^{3}$ has a target to restore over 2,000 ha of peatland in this area for community cultivation.

\subsection{Methods and data analysis}

We held in-depth interviews using open-ended questions with stakeholders in agarwood plantations. These interviews, which used purposive sampling, were analysed to understand the complex interplay between government policies and plans for smallholder agarwood plantations/gardens, and their application by local communities on the ground (Angelsen et al. 2011).

Interviewees included two officials from the Ministry of Environment and Forestry's Directorate General of Sustainable Production Forest Management and Directorate General of Natural Resources and Ecosystem Conservation, officials from the Bangka Belitung and South Kalimantan provincial governments, key farmers, local traders, and merchants. The interviews were conducted in 2019, in February and March in Bangka Belitung, in March in Jakarta, and in April and May in South Kalimantan. Interviews aimed to provide descriptive analyses of the following:

- local community practices in agarwood plantation production.

- policy options for sustaining agarwood production in Indonesia, particularly in the study areas.

2 The Banjar or Banjarese people are native to the southern part of Borneo. The general population is considered to be a mix of ethnic Sumatran Malay and Ma'anyan Kalimantan with a mixture of Malay and Ma'anyan genetic traits (77:23) (Brucato et al. 2016). The Banjarese people have strong cultural ties to rivers (wetlands) (Marini and Sapriya 2019).

3 The Peatland Restoration Agency or Badan Restorasi Gambut (BRG) is a non-structural government institution established under the administration of President Joko Widodo through Presidential Regulation No. 1/2016. BRG was established in response to the severe fire and haze disaster in 2015. It operates on over 2 million ha of degraded peatlands in seven provinces in Indonesia: Riau, Jambi, South Sumatra, West Kalimantan, Central Kalimantan, South Kalimantan and Papua. BRG has targeted the restoration of 56,486 ha of degraded peatlands in South Kalimantan; 576,026 ha in Central Kalimantan; and 149,902 ha in West Kalimantan (https://brg.go.id/program-kerja/). 


\title{
3 Agarwood planting, degradation of natural agarwood and regulation in Indonesia
}

\begin{abstract}
Agarwood resin forms only in infected trees (Tan et al. 2019), and people have tended to cut down entire stands to search for these rare infected trees. Consequently, forest degradation and unsustainable production practices have led to agarwood-producing species facing extinction. While technologies such as sonic tomography can predict the presence of resin, they are still not widely used (Indahsuary et al. 2014). This means agarwood producing countries must limit annual exports for more sustainable production. Agricultural practices and technologies could provide solutions for people to maintain agarwood production. Many traders prefer natural agarwood for its "wild scent" over the "human-made" agarwood sourced from plantations (Al Jazeera English 2016; Ash and Nguyen 2020). Hence, the market for natural agarwood is still relatively high, which contributes to unsustainable production and degradation of natural forests.
\end{abstract}

Several agarwood species from Aquilaria and Gyrinops genera are listed in CITES Appendix II. ${ }^{4}$ To ensure their survival in the wild, any trading activity - especially international - should follow CITES regulations. Quotas are applied to species trading and distribution, particularly for products harvested from nature (non-cultivated trees) (interview with Ditjen KSDAE official, April 2019). National focal points regulate the national status of species listed in CITES (Ibid). The national focal point in Indonesia is the Indonesian Institute of Sciences (LIPI), which sets quotas for listed species (Ibid).

Provisions governing the utilization of NTFPs, including agarwood, are laid out in several ministerial regulations, including Minister of Forestry Regulation No. 35/2007, ${ }^{5}$ which regulates NTFPs from flora and fauna sources (interview with Ditjen PHPL official, April 2019). Use of NTFPs is regulated through Government Regulation No. 3/2008, ${ }^{6}$ which includes exploitation (pengusahaan) and utilization (pemanfaatan). Meanwhile, Government Regulation No. 6/2007 requires any utilization of NTFPs to be licensed $\left(\right.$ Ibid).$^{7}$

Quotas do not apply to agarwood from plantations. Director General for Forest Protection and Nature Conservation Regulation No. P.25/IV-SET/ $2014^{8}$ regulates agarwood plantations (interview with Ditjen KSDAE official, April 2019). All agarwood plantations are expected to register with the Directorate General of Natural Resources and Ecosystem Conservation (Ditjen KSDAE) under MoEF (Ibid). The directorate uses this information to control and map agarwood trading (Ibid). The registration process is in its introductory phase with the government encouraging farmers to register their plantations (Ibid). Farmers are not obliged to register prior to planting but are encouraged to do so before harvests (Ibid). The system allows registration of groups as well as individual farmers (Ibid). Initially,

4 All species which although not necessarily now threatened with extinction may become so unless trade in specimens of such species is subject to strict regulation in order to avoid utilization incompatible with their survival; (Convention on International Trade in Endangered Species of Wild Fauna and Flora, Article II, paragraph 1).

5 Ministry of Forestry Regulation No. P.35/ Menhut-II/2007 on Non-Timber Forest Products.

6 Government of Indonesia Regulation No. 3/2008 on Revision to Government Regulation No. 6/2007 on Forest Arrangement and Preparation of Forest Management and Utilization Plans.

7 Government of Indonesia Regulation No. 6/2007 on Forest Arrangement and Preparation of Forest Management and Utilization Plans.

8 Director General for Forest Protection and Nature Conservation Regulation No. P.25/IV-SET/2014 on Agarwood Cultivation and Breeding Registration Procedures. 
the regulation only covered plantations on private or non-forest estate land (Ibid). Thus, the many agarwood plantations under social forestry schemes in state forest estate were yet to be covered by government policy (Wahyuni 2018).

In a later development, the regulation permitted farmers to sell products, but traders/brokers had to possess trading permits (izin edar) and ensure products were purchased from registered plantations (interview with Ditjen KSDAE official, April 2019). There is no quota system for agarwood plantations as harvesting is monitored through harvest reports or Berita Acara Panen (Ibid).

Constraints encountered in the field included inconsistent agarwood production and quality; unclear regulation of commerce; and unsupportive regulations for farmers. Among other areas, initial design, product diversification, and upstream and downstream integration could be improved. With respect to commerce, transparent regulation is required - a 'one-gate system' of business licensing process that simplifies investment and permit processes in Indonesia. The product also requires standardization, although this will remain difficult since it relies on intangible assessments from fragrance experts to determine quality and price. Climatic conditions also affect production; different Aquilaria spp. from Kalimantan often require a dry season for good seedlings (interview with a female farmer, May 2019). Farmers need to avoid cross breeding to maintain genetic purity (lbid). 


\section{Case studies from agarwood planting areas}

\subsection{Plantation systems}

Many agarwood plantations have resulted from government programmes. In Balangan, South Kalimantan, for example, the district government required farmers to plant agarwood as a requirement for being provided with fertilizer. There have been variations of this policy in Bangka. Farmers in Bangka were grouped into different cooperatives. However, many less experienced farmers often hesitated to inoculate mature trees. They lacked inoculants to infect trees effectively and lacked experience and knowledge about agarwood in general. Such farmers often replaced mature trees with oil palm to make their land more economically productive.

Agarwood seedlings have mostly been provided free as assistance to local communities, which are required to plant agarwood between rubber and oil palm stands. However, Bangka has a more varied system, which includes planting trees in house lots and home gardens, as well as single tree planting. Plantations in Bangka vary in size from 0.5-2 ha, with large-scale plantations of more than 2 ha established by the private sector.

Wild agarwood is usually formed through natural processes, e.g., wild animal grazing, lightning, friction, wind, etc., which damage the trees (Rasool and Mohamed 2016). Wounded trees are then infected by spores or hyphae of abundant fungi that flourish in the wild under appropriate humidity and energy conditions (Turjaman et al. 2016). The wounds and fungal infections activate the trees' natural defence mechanism, which produces agarwood resin (Turjaman, Hidayat and Santoso 2016; Tan et al. 2019). Community plantations and artificial inducement have been introduced as solutions to address the depletion of natural agarwood. Turjaman et al. (2016) and Tan et al. (2019) described three distinct methods of artificial tree induction:

a. Physical-mechanical

With this basic concept, trees are wounded to trigger their defence mechanism, which will form agarwood resin. Removing bark, cutting, puncturing, and other types of physical wounding using axes, machetes and spikes are common methods. Although this method is relatively low-cost, the quality of the resulting resin is inconsistent, and it will only be formed in the location of the wound.

b. Chemical

Different varieties of acid, including jasmonic, sulphuric and acetic, as well as alcohol are common compounds infused into trees to stimulate the defence mechanism that forms resin. This method tends to produce high volumes of quality resin relatively swiftly. However, this method has questionable impacts on human health and the environment.

c. Biological

This method aims to improve the physical-mechanical approach. The wound section is infused with microbes that will emulate pathological infection of the natural resin-forming process. Fusarium sp. is the most common fungal strain used in this practice in Indonesia. Other potential fungal strains are Aspergillius sp., Penicillium sp., Xylaria, sp. and Chaetomium sp. This is a longterm process, and the quality of resin formed is inconsistent due to the use of different fungal species. However, the biological approach tends to be safer for humans and the environment as it mimics the natural agarwood resin formation process. 


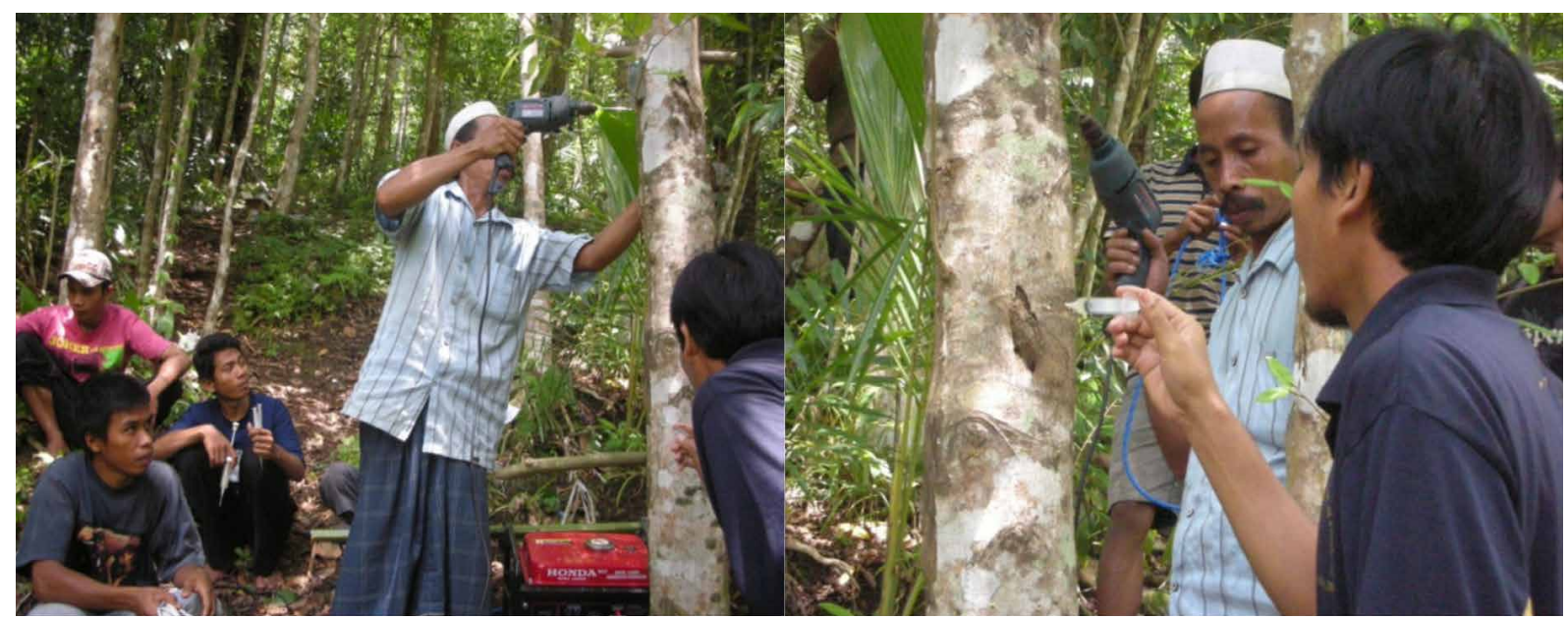

Figure 2. Induction process using the microbial-biological method. Photos were taken during the induction training in West Nusa Tenggara Province, organized by FORDA, Ministry of Forestry, Indonesia. (Turjaman, Santoso and Subiakto 2011)

Ineffective fungi-based inoculant formulae were the common finding in Bangka and Kalimantan. Farmers are more confident and find it more effective to use local inoculants developed independently by local actors or farmers. Farmers in South Kalimantan also preferred to use inoculant developed by the Malaysian Research Institute for its effectiveness in producing resin rather than inoculants developed by research institutes in Indonesia. Unfortunately, we found lack of development of inoculant formulae involving farmers or communities in any of our study locations. Several farmers had applied the wounding method to tree stems to cause stress to plants, but this method rarely succeeded in forming resin. Interestingly, farmer interviewees said that animalinflicted wounds to trees are often more successful in producing resin. In Kalimantan, for example, trees wounded by ruddy treeshrews (Tupaia splendidula) produced resin more successfully than trees wounded with human help. Complex biodiversity structures, including tree-animal interactions, also create the quality of fragrance preferred by consumers (Al Jazeera English 2016; Naziz et al. 2019). Increasing ruddy treeshrew populations could increase the probability of successful stem wounding from animals. As well-functioning ecosystems with complex biodiversity will likely produce a better fragrance of resin, agarwood gardens should have plentiful biodiversity to mimic natural tropical rainforest ecosystems.

\subsection{Products and marketing}

Agarwood farmers can sell their products in different forms, with logs, small logs or chips being the main options. Chips can be sold at higher prices and their quality is easier to maintain. Logs (whole tree trunks) are seldom chosen as farmers would often be gambling on the quality of resin formed in the tree. As farmers must pay people to cut wood chips, if the formed resin is low quality, they will be unable to pay for the labour. Many farmers also harvest agarwood trees section by section, avoiding direct tree cutting. According to a farmer/trader who deals with Middle Eastern buyers, the Middle East has technology to produce chips automatically, while in Southeast Asia they must be cut manually. Therefore, relevant stakeholders need to mutually work to enhance its use of technology in processing chips to improve its competitiveness.

Farmers in South Kalimantan sell high quality agarwood chips for IDR 6 million or approximately USD 421 per kilogram $(\mathrm{kg}$ ) and average quality chips for IDR 2-3 million or USD 140-210 for target markets in the Middle East (interview with a female farmer, May 2019). Meanwhile, our investigations of local markets showed lower quality agarwood being sold in the form of small logs for IDR 300,000 or USD 21 per kg (interview with a female trader, May 2019). ${ }^{9}$

9 USD $1=$ IDR 14,230 per 7 November 2020. 
Table 2. Agarwood market prices in South Kalimantan

\begin{tabular}{lccc}
\hline Quality & Unit & Type & Price/unit (USD) \\
\hline High & $\mathrm{kg}$ & Chip & 421 \\
\hline Average & $\mathrm{kg}$ & Chip & $140-210$ \\
\hline Low & $\mathrm{kg}$ & Log & 21 \\
\hline Undefined & tola $(6 \mathrm{cc})$ & Liquid & 140 \\
\hline Undefined & $\mathrm{kg}$ & Powder & 4.25 \\
\hline
\end{tabular}

Sources: Interviews with a female farmer and traders in South Kalimantan, May 2019

Some farmers also sell agarwood products in the form of perfume to intermediaries and Middle Eastern traders. The farmers we found in the field often only use roots or other underused parts of trees after chips have been cut to refine a perfume. One $\mathrm{kg}$ of tree parts can produce $1.2 \mathrm{grams}$ of perfume oil. The refining processes requires 72 hours with $20 \mathrm{~kg}$ having the capacity to produce $25 \mathrm{cc}$ of perfume, which is sold by the tola $(6 \mathrm{cc})$. The price per tola is around IDR 2 million or approximately USD 140. Refining requires constant fuel and firing, which poses a cost challenge for Indonesian agarwood entrepreneurs (interview with a female farmer, May 2019).

Agarwood is also sold as incense cones and powder. The price of incense powder is IDR 60,000 (USD 4.23) per kg, while 10 incense cones cost IDR 100,000 (USD 7). One local trader also sells agarwood resin in the form of prayer beads for IDR 75,000-125,000 (USD 5.30-8.80). The trader also sells agarwood sap for IDR 25,000 (USD 1.75) per piece (interview with an agarwood trader, May 2019). Other possible forms are agarwood tea and coffee, although dedicated trees are needed for tea production to ensure quality.

Some smallholder farmers said they have difficulties transporting agarwood because requirements are too stringent. The local government is supposed to issue certificates and permits, and then forward them to the MoEF and CITES. However, the processes involved in obtaining business licenses and permits to transport small amounts of agarwood remain difficult and time consuming (see Minister of Forestry Decree No. 447/Kpts-II/2003 on Procedures for Gathering, Trapping and Distributing Plants and Wildlife). ${ }^{10}$ This contributes to rampant unmonitored trading.

Agarwood resin quality is categorized based on expert appraisals in each country, with traders often determining product quality and price. Hence, different standards may apply in different locations. This has become a barrier to identifying a country's agarwood production potential to an exact degree.

In plantations, determining tree numbers and inoculation treatments, and selecting the appropriate isolate to produce better infection area and quality are additional considerations. Environmental conditions can affect growth of the fungus Fusarium sp. and the period of viability and virulence of the fungus at the time of inoculation and after. The pathogen's virulence to its host will decrease if the pathogen is maintained in culture for an extended period (Agrios 2005). A decrease in carbon sources, such as glucose, glucosamine, chitin, starch, and nitrogen for growing hyphae could decrease spore viability (Tanada and Kaya 1993 in Tikupadang and Prayudyaningsih 2012). Virulence in fungi also determines the length and shortness of the area of infection (Subowo 2010).

10 This Minister of Forestry decree regulates the mechanism and bureaucratic process for trade in species listed in the CITES appendices. 
It is necessary to carry out maintenance and pest management to ensure trees are better primed and more responsive to receiving inoculation without it causing rot and tree death. According to Caruso and Kuc (1977) in Rahayu, Santoso and Wulandari (2010), drastic reductions in numbers of leaves can inhibit photosynthesis and then inhibit the formation of secondary metabolites. Fluctuating extents of infections can be caused by plants' defence systems against different pathogens (Azwin 2016).

Repeated inoculation also needs to be considered to increase the extent and result of infection. Muttaqin et al. (2007) and Ngatiman (2005) in (Noorhamsyah 2010) found infection areas would spread after repeated inoculation applications. Akhsan, Mardji and Sutisna (2015) reported that after six months of inoculation the symptoms of infection were reduced, inoculation holes would become smaller, and wounds would slowly heal. If the pathogenic fungi that infect agarwood cannot defeat the plant's defence system, aloes are not formed, and the injured plant parts can rot (Azwin 2016). However, research on the maximum growth of fungi in agarwood and appropriate timing for repeated inoculation is still absent.

Economic calculations for investment in inoculation to develop agarwood resin are essential to support agarwood plantation development. Suharti et al. (2011) calculated that investment in trees in the $15-40 \mathrm{~cm}$ diameter range provides a positive Net Present Value (NPV). Although different economic models and approaches should be explored - including calculations that cover variabilities in plant responses and effectiveness of inoculation formulae in different biophysical ecosystem conditions - for countries with Muslim majority populations such as Indonesia, calculations using Sharia economic dimensions will be more attractive for local communities, and also for investors from the Middle Eastern countries that constitute some of the largest markets for Indonesian agarwood.

Good management of post-harvest products is crucial. Derivative agarwood products could generate additional value and help stabilize prices for raw harvested agarwood. Post-harvest agarwood products include essential oil for perfumes and soaps, powder from waste products for incense and mosquito repellent, and tea. Based on the study in South Kalimantan, agarwood tea might require dedicated trees for tea production to prevent contact with other post-harvest processes and products. Upstream development needs to be reassessed for agarwood tea as production requires pole heights of 1-2 metres for optimum harvests. Meanwhile tea production also requires herbal or traditional medicine standardization for commercial purposes and proper registration with the Indonesian National Agency of Drug and Food Control or Badan Pengawas Obat dan Makanan (BPOM).

Development of post-harvest products can contribute to the establishment of micro, small and medium enterprises (MSMEs) and cooperatives. More marketing and promotion could help motivate farmers to plant agarwood. In addition, regular participation in trade fairs in the Middle East could also strengthen the industry. This requires solid cooperation between stakeholders at the national level, including the Ministry of Cooperatives and SMEs; related ministries such as the Ministry of Trade and Ministry of Industry; embassies and trade consulates; and trader network associations such as the Indonesian Agarwood Association, Agarwood Farmers Association, Indonesian Young Entrepreneurs Association and the Indonesian Chamber of Commerce. 


\section{Developing paludiculture in degraded peatlands}

Local plantation, mainly through agroforestry, has been known to provide opportunities for livelihood improvement without compromising the environment (Persoon and van Beek 2008).

The planting of species to substitute for products being extracted from nature could help conserve commodity species such as agarwood. Agarwood plantations provide an opportunity to explore this idea as local communities are already familiar with the species. Agroforestry, for example, can provide alternative incomes for people living near natural forest, while encouraging them to protect it (Murniati et al 2001). Agroforestry with appropriate compositions of trees and crops can improve soil nutrition compared to monoculture practices, and generate income throughout the year, which can enhance household well-being (Nair 1993).

However, to improve agarwood plantations, farmers need knowledge and equipment to meet the quality standards demanded by international buyers. The industrial sector could support farmers through partnership programmes that offer capital, land, labour, training, and contracts to buy their products. This would make the idea of conservation through plantation plausible.

Agarwood plantation agroforestry could become a feasible option for reducing loss of agarwood species in nature, while restoring the vast areas of degraded land and providing alternative income sources for local communities. The many kinds of agarwood-producing species present opportunities to restore different types of degraded ecosystems by matching species growth requirements with the physical characteristics of those ecosystems. As an example, after the huge peatland fires in 2015, the Ministry of Environment and Forestry stated that agarwood should be included as a species for restoring degraded peatlands (Wulandari 2015).

Agarwood species grow naturally on lowlands and peat-swamp ecosystems (Susilo and Denny 2016; Giesen and Nirmala 2018). Indeed, agarwood was one of the main commodities during the days of the Srivijaya Empire in what is now South Sumatra, and peat and agarwood can still be found there (Wijaya 2016). Paludiculture - cultivation of trees and other plant species to maintain the characteristics of peat ecosystems (Tata and Susmianto 2016) - can use agroforestry to restore degraded peatlands, while providing reasonable livelihood options for local communities. Suwardi et al. (2009) showed that $80 \%$ of agarwood planted on acid sulphate soils in degraded peatlands in Jambi province (which have extremely low pH and are harmful to many crop species) grew healthily and even produced resin naturally. Thus, planting agarwood could be a solution for peatland restoration.

The Central Kalimantan Agriculture Technology Research Institute (BPTP 2014) has helped farmers in Jabiren village, Pulang Pisau district, Central Kalimantan to plant 500 agarwood trees on 2-ha plots. The cultivation system uses agroforestry, combining agarwood and rubber trees. The biological inoculation method was used on five-year-old trees to stimulate resin formation. Due to farmers' limited capital, a private partner was invited to carry out inoculations; farmers and investors shared yields 60:40, but farmers were also charged an additional IDR 50,000 or USD 3.51 per tree (BPTP 2014). Inoculations used the infusion method, where a microbe to infect trees was infused with a minimum diameter of $15 \mathrm{~cm}$ (Tabloid Sinartani/Anang Firmansyah 2014). 
Agro-silvofishery is a promising method for the development of agarwood gardens. Agarwood can be planted between stands in rubber plantations on mineral soil adjacent to peatlands, (where it is commonly developed by local communities in Kalimantan). Meanwhile, native agarwood species can be combined in peatlands with other species, which are traditionally cultivated by local communities in peat swamp areas. The local community can collect an abundant number of fish species as their food and livelihood source (Samsudin et al. 2020; Setiadi 2014). Local communities can also cultivate fish as integrated management with trees and other plants species for forestry and agriculture purposes (Samsudin et al. 2020).

At least 20 species of fungi are associated with resin formation. These include Torula sp., Fusarium sp., Lasiodiploidia sp., Aspergillus sp., Chaetomium sp. and Penicillium sp., but the number of fungal species keeps increasing (Nagajothi et al. 2016; Turjaman et al. 2016; Tan et al. 2019). Continuous attacks from fungi and the reactions of trees' defence mechanisms over several years, supported by appropriate environmental factors (such as temperature, humidity, soil fertility, light intensity, pests and disease) allow the formation of fine quality and abundant natural agarwood (Turjaman et al. 2016). The three most important success factors for both quantity and quality of agarwood are interaction with the genetic characteristics of the host plant, appropriate environmental conditions, and an abundance of endophytic fungi (Santoso 2013; Turjaman et al. 2016).

Native ethnic Malay people traditionally collect timber and NTFPs, including fish, from peat swamp forest ecosystems (Furukawa 2004). Many Indonesian farmers commonly use agroforestry to establish forest gardens. Examples are farmers in Lampung province using mixed dipterocarps in their repong damar agroforestry systems and farmers in South Kalimantan having fruit gardens in their dukuh/pulau buah (literally fruit island) systems (de Foresta et al. 2000; Samsudin et al. 2020).

In their physical appearance and ecosystem dynamics, traditional community forest gardens resemble secondary and primary natural forests (de Foresta et al. 2000). Farming that involves peat swamp reclamation causes land subsidence, so local people in South Kalimantan harness natural regeneration of gelam (Melaleuca cajuputi) to add organic material before re-working land as paddy fields. This avoids disturbing toxic pyritic sediments (Sumawinata 1992).

Degraded peatlands in Indonesia can be restored using traditional forest garden approaches, which resemble the structures and dynamics of natural forests (de Foresta et al. 2000). Different layers of natural forests or forest gardens consist of emergent, canopy, understory and forest floor species diversity. Multispecies forest garden farming will add more organic material, thus preserving peatland as the plants naturally sequester carbon. Plant diversity has a positive correlation with diversity of fungal communities (Maltz, Treseder and Mcguire 2017). As forest gardens resemble natural forest environments and have abundant fungal diversity, they could increase the quality and quantity of agarwood.

Development of cultivation knowledge of agarwood resin producing species that are found naturally in swamp ecosystems and lowland forests could become a promising strategy to be explored to optimize peatland restoration and enhance community livelihoods. These native swamp and lowland ecosystems agarwood species include Gonystylus bancanus, Excoecaria agallocha L., Dalbergia parviflora Roxb., Cantelya corniculata (Becc.), Aquilaria beccariana and Aquilaria filaria (Susilo and Denny 2016; Giesen and Nirmala 2018). Further research, particularly on silviculture and harvest systems, is needed to promote sustainable agarwood production in peat swamp ecosystems. 


\section{Key challenges and a way forward}

Agarwood plantations go beyond providing a solution to prevent loss of agarwood tree species in nature. They can also provide sustainable financial incentives and livelihoods for local communities, while restoring and conserving fragile peat swamp ecosystems. However, five key factors must be overcome to develop sustainable agarwood production that can help restore peatland:

a. Market access: Administrative processes should be improved to help smallholders/farmers market their products and promote sustainable agarwood production.

b. Artificial inducement: Difficulties accessing technologies and inoculant formulae have discouraged farmers from participating in planting agarwood. They would rather develop their land for other commodities such as oil palm as it provides quick cash for daily subsistence. Top quality agarwood requires long fungi attack and tree defense mechanism processes as they occur in nature (Turjaman et al. 2016). Even though revenues from agarwood can range from millions to hundreds of millions of rupiahs during harvest seasons, the long waits involved discourage farmers from developing agarwood. These long waits could be made more bearable by optimizing products and embracing forest garden agroforestry.

c. Initial investment for inoculation: Significant investment and expenditure is necessary for inoculation to produce agarwood resin effectively. Our findings show local communities struggling to choose appropriate inoculation technologies and methods. Inoculation costs are affected by the variety of formulae, technologies, application methods and doses. Any miscalculations might result in ineffective inoculation and incur losses for local communities.

d. Processing facilities: Affordable technologies are needed for processing agarwood into more competitive products, such as essential oil.

e. Development of different agarwood tree species: Indonesia is blessed with high plant diversity. The development and cultivation of lesser-known agarwood species still needs to be enhanced, particularly for native peat swamp species.

To address these issues, the MoEF and other relevant agencies needs to develop a bottom-up policy that identifies problems in the field that can be addressed by national and regional government policies and regulations. Taking account of biophysical characteristics, as well as the cultures and needs of local communities, agarwood can be developed using paludiculture by mimicking natural forest systems to restore degraded peat swamp ecosystems. Silviculture and harvesting techniques need to be developed further for lesser-known agarwood species.

Development of technologies and processing techniques in its post-harvest industries is necessary to produce innovative and better-quality agarwood products, including harvest biproducts and waste products. Collaboration between stakeholders, including farmers, local governments, local universities and foreign organizations, could initiate technology transfer to address problems facing local farmers.

Agarwood development is now on track to be run and managed by local communities. Local communities in Kalimantan and across Indonesia have known about agarwood for hundreds of years. Building the capacity of farmer groups and their cooperatives could motivate farmers to pursue sustainable agarwood plantation practices. This would include supporting training for better marketing, as well as providing financial incentives to conserve and restore degraded landscapes, including carbon-rich peat swamp ecosystems. 
Many local communities in Indonesia traditionally practice agroforestry where their forest gardens resemble the structures and dynamics of natural forests (de Foresta et al. 2000). Such practices could be re-introduced to restore vast areas of degraded peatlands, where various plant species would add organic material to peat and help repair damaged peat swamp ecosystems. At the same time, environmental conditions in diverse forest gardens that resemble natural forests and have abundant fungal species diversity can help produce high quality agarwood in sufficient quantities. Nevertheless, better marketing and innovative economic strategies would be needed to improve community livelihoods in this context. 


\section{References}

Agrios, G. N. 2005. Plant Pathology. Fifth Edit. USA: Elsevier Academic Press.

Akhsan, N., D. Mardji, and M. Sutisna. 2015. "Response of Aquilaria Microcarpa to Two Species of Fusarium under Two Different Cultivation Systems." Journal of Tropical Forest Science 27(4):447-55.

Angelsen, A., H. O. Larsen, J. F. Lund, C. Smith-Hall, S. Wunder, and (eds.). 2011. "Measuring Livelihoods and Environmental Dependence: Methods for Research and Fieldwork." 240p.

Antaranews.com. 2011. "Balangan Kembangkan 125.000 Pohon Gaharu." Retrieved March 17, 2021 (https://kalsel.antaranews.com/berita/5013/balangan-kembangkan-125000-pohon-gaharu).

Ash, Andy, and Hang Nguyen. 2020. "Why Agarwood Is So Expensive | So Expensive - YouTube BusinessInsider."

Azwin. 2016. "Inokulasi Fusarium Sp. Pada Pohon Karas (Aquilaria Malaccencis Lamk.) Terhadap Pembentukan Gaharu." Jurnal Kehutanan 11(2):60-75.

BPTP. 2014. "Proses Infus Gaharu Dan Hasilnya Setelah 4 Bulan Di Wanatani Lahan Gambut Desa Jabiren Kalimantan Tengah." Info Teknologi. Retrieved November 9, 2020 (http://kalteng.litbang. pertanian.go.id/ind/index.php/publikasi-mainmenu-47-47/teknologi/313-proses-infus-gaharudan-hasilnya-setelah-4-bulan-di-wanatani-lahan-gambut-desa-jabiren-kalimantan-tengah).

Brucato, Nicolas, Pradiptajati Kusuma, Murray P. Cox, Denis Pierron, Gludhug A. Purnomo, Alexander Adelaar, Toomas Kivisild, Thierry Letellier, Herawati Sudoyo, and François Xavier Ricaut. 2016. "Malagasy Genetic Ancestry Comes from an Historical Malay Trading Post in Southeast Borneo." Molecular Biology and Evolution 33(9):2396-2400. doi: 10.1093/molbev/msw117.

Burhan. 2009. Strategi pengembangan hutan tanaman unggulan lokal di provinsi Nusa Tenggara Barat. Masters thesis, Institut Pertanian Bogor. Bogor, Indonesia: Institut Pertanian Bogor.

Carlson, KM, LM Curran, ... D. Ratnasari-Proceedings of the, and Undefined 2012. 2012. "Committed Carbon Emissions, Deforestation, and Community Land Conversion from Oil Palm Plantation Expansion in West Kalimantan, Indonesia." National Acad Sciences.

Compton, James, and Akiko Ishihara. n.d. "The Use and Trade of Agarwood in Japan."

Elz, Ian, Kevin Tansey, Susan E. Page, and Mandar Trivedi. 2015. "Modelling Deforestation and Land Cover Transitions of Tropical Peatlands in Sumatra, Indonesia Using Remote Sensed Land Cover Data Sets." Land 4(3):670-87. doi: 10.3390/land4030670.

Faizal, Ahmad, Rizkita Rachmi Esyanti, Elfa Norisda Aulianisa, Iriawati, Erdy Santoso, and Maman Turjaman. 2017. "Formation of Agarwood from Aquilaria Malaccensis in Response to Inoculation of Local Strains of Fusarium Solani." Trees - Structure and Function 31(1):189-97. doi: 10.1007/ s00468-016-1471-9.

de Foresta, H., A. Kusworo, G. Michon, and WA Djatmiko. 2000. Ketika Kebun Berupa Hutan: Agroforest Khas Indonesia. Sebuah Sumbangan Masyarakat. edited by H. de Foresta, A. Kusworo, G. Michon, and W. Djatmiko. Bogor, Indonesia: International Centre for Research in Agroforestry; Institut de Recherche pour le Développement; Ford Foundation.

Furukawa, Hisao. 2004. "The Ecological Destruction of Coastal Peat Wetlands in Insular Southeast Asia." P. 638 in Ecological destruction, health, and development: Advancing Asian paradigms, edited by H. Furukawa, N. Mitsuaki, K. Yasuyuki, and K. Yoshihiro. Kyoto, Japan: Kyoto University Press.

Gerber, Nicolas, and Robert J. Hill. 2005. "Sustainability and Market Structure in Renewable Natural Resource Markets: The Case of Gaharu in Papua New Guinea."

Giesen, Wim, and Eli Nirmala. 2018. Tropical Peatland Restoration Report : The Indonesian Case. Jakarta, Indonesia.

Huijnen, V., M. J. Wooster, J. W. Kaiser, D. L. A. Gaveau, J. Flemming, M. Parrington, A. Inness, D. Murdiyarso, B. Main, and M. van Weele. 2016. "Fire Carbon Emissions over Maritime Southeast Asia in 2015 Largest since 1997." Scientific Reports 6(1):1-8. doi: 10.1038/srep26886. 
Indahsuary, Ningsie, Dodi Nandika, Lina Karlinasari, and Erdi Santoso. 2014. "Reliability of Sonic Tomography to Detect Agarwood in Aquilaria Microcarpa Baill." Journal of the Indian Academy of Wood Science 11(1):65-71. doi: 10.1007/s13196-014-0119-x.

Al Jazeera English. 2016. "Scent From Heaven | Featured Documentary - YouTube." Documentary. Karlinasari, Lina, and Dodi Nandika. 2016. "Acoustic-Based Technology for Agarwood Detection in Aquilaria Trees." Pp. 137-48 in Agarwood: Science Behind the Fragrance, edited by R. Mohamed. Singapore: Springer.

Lee, Shiou Yih, and Rozi Mohamed. 2016. "The Origin and Domestication of Aquilaria, an Important Agarwood-Producing Genus." Pp. 1-20 in Agarwood: Science Behind the Fragrance, edited by R. Mohamed. Singapore: Springer.

Maltz, Mia R., Kathleen K. Treseder, and Krista L. Mcguire. 2017. "Links between Plant and Fungal Diversity in Habitat Fragments of Coastal Shrubland." 1-19. doi: 10.5061/dryad.13s7s.

Marini, and Sapriya. 2019. "Inheritance in Harmonizing Society from Old Generation to Young Generation through River Culture in Banjarmasin City." Pp. 389-93 in Proceeding International Conferences on Advances in Education, Humanities, and Language (ICEL) Mainstreaming the Influences on Higher Order of Thinking Skills in Humanities, Education, and Language in Industrial Revolution 4.0, edited by E. Setyawati, W. C. Perdhani, I. Emaliana, I. Febriyanti, D. Inayati, S. Sukmawan, I. Puspitasari, and A. Gozali. Malang: UB Press.

Ministry of Environment and Forestry Republic of Indonesia. 2019. Environmental and Forestry Statistics in 2018 (Statistik Lingkungan Hidup Dan Kehutanan Tahun 2018). Jakarta, Indonesia: Ministry of Environment and Forestry.

Murniati, D. P. Garrity, and A. Ng Gintings. 2001. "The Contribution of Agroforestry Systems to Reducing Farmers' Dependence on the Resources of Adjacent National Parks: A Case Study from Sumatra, Indonesia." Agroforestry Systems 52(3):171-84. doi: 10.1023/A:1012047602192.

Nagajothi, M. Sangareswari, K. T. Parthiban, S. .. Kanna, L. Karthiba, and D. Saravanakumar. 2016. "Fungal Microbes Associated with Agarwood Formation." American Journal of Plant Sciences 7(July):1445-52. doi: 10.4236/ajps.2016.710138.

Nair, P. K. R. 1993. An Introduction to Agroforestry Kluwer Academic Publishers. Dordrecht: Kluwer Academic Publisher.

Naziz, Pearlin Shabna, Runima Das, and Supriyo Sen. 2019. "The Scent of Stress: Evidence from the Unique Fragrance of Agarwood." Frontiers in Plant Science 10(July). doi: 10.3389/ fpls.2019.00840.

Nobuchi, Tadashi, and Somkid Siripatanadilok. 1991. "Preliminary Observation of Aquilaria Crassna Wood Associated with the Formation of Aloeswood." BULLETIN OF THE KYOTO UNIVERSITY FORESTS 63:226-35.

Noorhamsyah. 2010. “Pengaruh Beberapa Metode Inokulasi Terhadap Infeksi Jamur Dusarium Oxysporum Schlecht. Dan Acremonium Kiliense Grütz. Pada Pohon Gaharu (Aquilaria Malaccensis Lamk.)." Jurnal Kehutanan Tropika Humida 3(1):81.

Persoon, G. A., and H. H. van Beek. 2008. "Growing 'The Wood of The Gods': Agarwood Production in Southeast Asia." in Smallholder Tree Growing for Rural Development and Environmental Services: Lessons from Asia, edited by D. J. Snelder and R. D. Lasco. Springer.

Persoon, Gerard A. 2007. "Agarwood: The Life of a Wounded Tree." IIAS Newsletter 45:24-25.

Plantation and Forestry Agency of Central Bangka District. 2013. Roadmap Pengembangan HHBK Kabupaten Bangka Tengah Sebagai Klaster Gaharu Tahun 2014-2028. Central Bangka, Indonesia.

Rahayu, Gayuh, E. Santoso, and E. Wulandari. 2010. "Efektivitas Dan Interaksi Antara Acreminium Sp. Dan Fusarium Sp. Dalam Pembentukan Gubal Gaharu Pada Aquilaria Microcarpa Baill." Info Hutan VII(2):155-64.

Rasool, Saiema, and Rozi Mohamed. 2016. "Understanding Agarwood Formation." Pp. 39-56 in Agarwood: Science Behind the Fragrance, edited by R. Mohamed. Singapore.

Samsudin, Yusuf Bahtimi, Dyah Puspitaloka, Syed Ajijur Rahman, A. Chandran, and Himlal Baral. 2020. "Community-Based Peat Swamp Restoration Through Agroforestry in Indonesia." Pp. 349-65 in Agroforestry for Degraded Landscapes: Recent Advances and Emerging Challenges - Vol.1, edited by J. C. Dagar, S. . Gupta, and D. Teketay. Singapore: Springer. 
Santoso, Erdy. 2013. "Agarwood Formation by Fungal Bioinduction Technology." P. 294 in Track record: agarwood inoculation technology, edited by A. Susmianto, M. Turjaman, and P. Setio. Bogor, Indonesia: Forda Press.

Schmidt, Milena Sosa. 2011. INTRODUCTION TO CITES AND AGARWOOD OVERVIEW Asian Regional Workshop on Agarwood.

Setiadi, Bambang. 2014. "Aquaculture and Tropical Peatland Fishery." Pp. 58-60 in Towards climateresponsible peatlands management, edited by R. Biancalani and A. Avagyan. Rome, Italy: FAO.

Subowo, Yohanes Bernard. 2010. "JAMUR PEMBENTUK GAHARU SEBAGAI PENJAGA KELANGSUNGAN HIDUP TANAMAN GAHARU (Aquilaria Sp)." Jurnal Teknik Lingkungan 11(2):167-73.

Suharti, Sri, Pratiwi Pratiwi, Erdy Santoso, and Maman Turjaman. 2011. "Feasibility Study of Business in Agarwood Inoculation at Different Stem Diameters and Inoculation Periods." Indonesian Journal of Forestry Research 8(2):114-29. doi: 10.20886/ijfr.2011.8.2.114-129.

Sumawinata, Basuki. 1992. "Adaptive Agricultural Practices and Land Use Cycles on Pyritic Sediments in South Kalimantan." Southeast Asian Studies 30(1):93-104.

Susilo, Adi, and Denny. 2016. "Jenis-Jenis Penghasil Gaharu Yang Kurang Dikenal." Pp. 101-14 in Membangun Hasil Hutan yang Tersisa, edited by M. Bismark and E. Santoso. Bogor, Indonesia: Forda Press.

Suwardi, Basuki Sumawinata, Darmawan, Gunawan Djajakirana, and Hermanu Wijaya. 2009. "Utilization of Acid Sulfate Soil in Rantau Rasau-Jambi Province for Cultivation of Gaharu (Aquilaria Sp)." Pp. 185-89 in Proceedings of Bogor Symposium and Workshop on Tropical Peatland Management, Bogor, Indonesia, 14-15 July 2009 "Wise Use of Tropical Peatland," edited by Sudarsono, R. Hatano, T. Inoue, S. Limin, G. Djajakirana, and Suwardi. Bogor, Indonesia: Bogor Agriculture University, Hokkaido University.

Tabloid Sinartani/Anang Firmansyah. 2014. "Infus Gaharu Lahan Gambut." Tabloid Sinar Tani Web Page. Retrieved March 18, 2021 (https://tabloidsinartani.com/detail/indeks/kebun/829-infusgaharu-lahan-gambut).

Tan, Cheng Seng, Nurulhikma Md Isa, Ismanizan Ismail, and Zamri Zainal. 2019. "Agarwood Induction: Current Developments and Future Perspectives." Frontiers in Plant Science 10(February):1-13. doi: 10.3389/fpls.2019.00122.

Tata, Hesti L., and Adi Susmianto. 2016. Prospek Paludikultur: Ekosistem Gambut Indonesia. Bogor, Indonesia: FORDA Press.

Tikupadang, H., and R. Prayudyaningsih. 2012. "Identifikasi Dan Keberadaan Tuymbuhan Penghasil Gaharu Serta Identifikasi Mikroba Pembentuk Gubal Gaharu Di Sulawesi." P. 135 in Prosiding Ekspose Hasil-Hasil Penelitian Balai Penelitian Kehutanan Makassar.

Turjaman, Maman. 2016. Pengembangan Cluster Produksi Gaharu Berbasis Teknologi Mikrob. edited by E. Santoso and M. Bismark. Bogor: Forda Press.

Turjaman, Maman, and Asep Hidayat. 2016. "Gaharu Alam Indonesia Semakin Langka, Mampukah Gaharu Budidaya Berbasis Mikroba Endofitik Menggantikannya?" in Membangun Hasil Hutan yang Tersisa, edited by M. Bismark and E. Santoso. Bogor, Indonesia: Forda Press.

Turjaman, Maman, and Asep Hidayat. 2017. "Agarwood-Planted Tree Inventory in Indonesia." IOP Conf. Series: Earth and Environmental Science 54. doi: 10.1088/1755-1315/54/1/012062.

Turjaman, Maman, Asep Hidayat, and Erdy Santoso. 2016. "Development of Agarwood Induction Technology Using Endophytic Fungi." Pp. 57-71 in Agarwood, edited by R. Mohamed. Singapore: Springer.

Turjaman, Maman, Erdy Santoso, and Atok Subiakto. 2011. Training of Forest Communities of The Inoculation Technology Training of Forest Communities of The Inoculation Technology. Technical Report No. 5. Bogor, Indonesia.

Wahyuni, Tien. 2018. "Peraturan Direktur Jenderal PHKA Tentang Tata Cara Registrasi Penangkaran/ Budidaya Gaharu Perlu Ditinjau Kembali." Article. Retrieved November 8, 2020 (https://www. diptero.or.id/peraturan-direktur-jenderal-phka-tentang-tata-cara-registrasi-penangkaranbudidaya-gaharu-perlu-ditinjau-kembali/).

Wijaya, Taufik. 2016. "Melacak Budaya Peduli Lingkungan Masyarakat Gambut Di Nusantara." Mongabay Indonesia. Retrieved June 30, 2018 (http://www.mongabay.co.id/2016/10/06/ melacak-budaya-peduli-lingkungan-oleh-masyarakat-gambut-di-nusantara/).

Wulandari, I. 2015. "Cara Menteri Siti Berdayakan Lahan Gambut | Republika Online.” 


CIFOR Working Papers contain preliminary or advance research results on tropical forest issues that need to be published in a timely manner to inform and promote discussion. This content has been internally reviewed but has not undergone external peer review.

Agarwood resin, produced by certain evergreen tree species native to Southeast Asia, is used for making incenses, medicines and fragrances. A precious commodity for centuries, it has a current market value of USD 32 billion, projected to reach USD 64 billion by 2029 (Ash and Nguyen 2020). However, high trading frequency has led to agarwood species being threatened with extinction in the wild. In response, the Government of Indonesia is promoting agarwood plantations to decrease overexploitation on wild agarwood trees. Under Indonesia's Nationally Determined Contribution (NDC), the government has targeted the restoration of 14 million hectares (ha) of degraded land including 2 million ha of peatlands by 2030. In addition to restoring biophysical characteristics to recover ecosystem services, the government's plan provides an opportunity to strengthen climate-resilient livelihoods for local farmers in Kalimantan. Here we review and assess the development of these plantations and the viability of agarwood as a commodity for climate-resilient livelihood options for peatland ecosystem-reliant communities. We found farmers using climate smart agroforestry approaches in planting agarwood, combining it with rubber and other tree species. Plantation-grown agarwood trees require artificial inducement to produce the valuable resinous substance known as 'agarwood resin' or simply 'agarwood'. Local communities are facing major problems with artificial inoculation methods and application. Meanwhile, market potential and trade commerce administration need further development. Agroforestry systems that promote biodiversity by combining agarwood tree species with other non-timber forest products (NTFPs) could enhance local community livelihoods and increase the quality of the agarwood resin they produce.

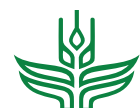

Forests, Trees and

CGIAR Agroforestry research for development program to enhance the role of forests, trees and agroforestry in sustainable development and food security and to address climate change. CIFOR leads FTA in partnership with ICRAF, the Alliance of Bioversity International and CIAT, CATIE, CIRAD, INBAR and TBI.

FTA's work is supported by the CGIAR Trust Fund: cgiar.org/funders/

\section{cifor.org | forestsnews.cifor.org}

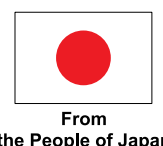

the People of Japan

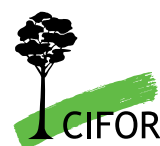

Center for International Forestry Research (CIFOR)

CIFOR advances human well-being, equity and environmental integrity by conducting innovative research, developing partners' capacity, and actively engaging in dialogue with all stakeholders to inform policies and practices that affect forests and people. CIFOR is a CGIAR Research Center, and leads the CGIAR Research Program on Forests, Trees and Agroforestry (FTA). Our headquarters are in Bogor, Indonesia, with offices in Nairobi, Kenya; Yaounde, Cameroon; Lima, Peru and Bonn, Germany.

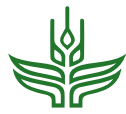

CGIAR 